\title{
MYH11 Gene
}

National Cancer Institute

\section{Source}

National Cancer Institute. MYH11 Gene. NCI Thesaurus. Code C29957.

This gene plays a regulatory role in muscle contraction and the required ATP hydrolysis. 